\title{
Direct Mass Spectrometric Analysis of Zinc and Cadmium in Water by Microwave Plasma Torch Coupled with a Linear Ion Trap Mass Spectrometer
}

Tao Jiang ${ }^{1}$, Xiaohong Xiong ${ }^{1}$, Shangxian Wang ${ }^{1}$, Yanling Luo ${ }^{1}$, Qiang Fei ${ }^{2}$, Aimin $\mathrm{Yu}^{2}$, Zhiqiang $\mathrm{Zhu}^{1}$ *

1. Jiangxi Key Laboratory for Mass Spectrometry and Instrumentation, East China University of Technology, Nanchang 330013, China

2. College of Chemistry, Jilin University, Changchun 130021, China

*Correspondence to: Zhiqiang Zhu, Jiangxi Key Laboratory for Mass Spectrometry and Instrumentation, East China Institute of Technology.E-mail: zhiqiangz@iccas.ac.cn;

Prepared for International Journal of Mass Spectrometry 


\begin{abstract}
Microwave plasma torch (MPT) is a simple and low power-consumption ambient ion source. When MPT Mass spectrometry is applied in the detection of some metal elements, the metallic ions exhibit some novel features which are different with traditional ICP Mass spectrometry and may be helpful for the metal element analysis. Zinc and cadmium both are important transition metals with wide applications in modern industry. Here, we presented the research results about the MPT mass spectra of zinc and cadmium elements by a linear ion trap mass spectrometer (LTQ) both in positive and negative mode. Without any sample pretreatment, the aqueous samples were pneumatically nebulized and generated the aerosols. The dried aerosols were introduced into the plasma through the central tube of the MPT to generate the complex metallic ions. For the positive composite ions of zinc and cadmium, the general forms are the hybrid of $\mathrm{M}\left(\mathrm{NO}_{3}\right) \bullet \mathrm{nOH} \bullet \mathrm{mH}_{2} \mathrm{O}$, thus the MPT mass spectra are extremely complicated and unsuitable for the quantitative monitoring. However, the MPT negative ionic of zinc and cadmium are quite regular in the forms of $\mathrm{M}\left(\mathrm{NO}_{3}\right)$. We also showed the limit of detection (LOD) for zinc and cadmium in negative mode can achieve at the level of $10 \mu \mathrm{g} / \mathrm{L}(\mathrm{ppb})$. Therefore, the negative mode MPT mass spectrometry can be used as one of alternative supplements of ICP-MS applied in on-line monitoring of zinc and cadmium metal ions in water at trace levels, which will be promising in the field analysis of metal elements and the rapid water quality inspection.
\end{abstract}

Keywords: microwave plasma torch; linear ion trap mass spectrometry; zinc; cadmium; water inspection 


\section{INTRODUCTION}

Zinc and cadmium are both the metal elements of IIB group in the period table and have extensive applications in modern industries. Their chemical properties are similar and so zinc and cadmium always associated in the natural world. Zinc is one of indispensable trace elements in living body, and plays a very important role in human metabolism [1]. Indeed, zinc deficiency in human body may have effects on almost all parts of the human immune system [2] and then lead to a series of diseases [3], such as maldevelopment, hypoimmunity, mental retardation, and so on. However, cadmium is a famous toxic heavy metal element [4, 5]. The extensive use of cadmium can contaminate seriously the environment and damage the health of human being $[6,7]$. Some researches showed that cadmium mainly affects the enzyme system zinc contained[8,9]. On the other hand, zinc has also buffer effect on cadmium toxic for many crops, for example, wheat and corn $[10,11]$. Currently, scientists are increasingly aware of the index of zinc cadmium ratio in biological system, which is more important rather than the content of single cadmium element [12]. Developing the rapid and direct method for the quantitative measurement of zinc and cadmium will be an efficient approach.

The analytical methods for zinc and cadmium elements are mainly traditional. Recently, Liu et al. [13] developed a high sensitive fluorescent probe technique which can monitor cadmium in aqueous solutions and living cells with low detection limit of $20 \mathrm{nM}$. But this method is highly selective and may be not suitable for the detection of zinc. Inductively coupled plasma mass spectrometry (ICP-MS) [14-16] is quite sensitive element analysis method and can determine the contents of zinc and cadmium [17]. Nevertheless, in the current field analytical sense, ICP-MS is yet limited due to the general essential, tedious chemical pretreatment, expensive and cumbersome equipments. The microwave plasma torch (MPT) mass spectrometry [18-22] is one of lately developed ambient mass spectrometric techniques with multi-advantages, including low-power consumption, easy operation, simple 
construction, strong excitation ability, and so on. More early, MPT had been used as a powerful light source and applied widely in spectrometric instruments [23, 24]. Our previous studies [25] have showed that the MPT ion source coupled with a mass spectrometer can is a promising analytical tool in various fields. Adopting the desolvation unit, and injecting aqueous samples through the central-tube of MPT, the MPT mass spectrometry can be used to detect directly sensitively many kinds of metal elements in water, without tedious sample pretreatment. Thus the MPT mass spectrometry can be used as the supplementary of ICP MS and has potential applications in field analysis.

To expand further the applications of MPT-MS in metal element analysis in water, especially in the detection of zinc and cadmium, the in-depth studies about the feature MPT mass spectra of zinc and cadmium are necessary. This article presented the MPT mass spectra of zinc and cadmium both in positive mode and negative mode of linear ion trap (LTQ) mass spectrometer. The cations and anions of zinc and cadmium complexes were characterized by multistage collision induced dissociation (CID) experiments. Moreover, primer results showed that the LOD for the detection of zinc and cadmium in water are at the levels of $10 \mu \mathrm{g} / \mathrm{L}$. These results established the basic of the practical applications of MPT mass spectrometry in the fields of environment controlling and the water quality inspection for zinc and cadmium elements.

\section{EXPERIMENTAL Materials and Reagents}

Aimin Yu's group at Jilin University of China provided the MPT for this experimental research. The $2450 \mathrm{MHz}$ microwave generator (YY1-50 W-2450) with maximum power 50 W and the coaxial line (SFCJ-50-9) were purchased from the Nanjing Electronic Technology Co., Ltd. (Nanjing, China). High purity argon (99.999\%) (the Guoteng Special Gas Ltd., Nanchang, China) is used as the MPT assisted gas. Zinc and cadmium standard solution (1.0 
$\mathrm{g} / \mathrm{L} \mathrm{Zn}$ or $\mathrm{Cd}$ in $1.0 \mathrm{~mol} / \mathrm{L} \mathrm{HNO}_{3}$ ) were purchased from were purchased from Sinopharm Chemical Reagent Co., Ltd. The water used was deionized water provided by the chemistry facilities in the East China Institute of Technology (ECIT).

\section{Instrumental Setup}

A commercial linear ion trap (LTQ XL) mass spectrometer (Thermo Fisher Scientific, San Jose, CA, USA) combined with a MPT as the ion source was employed in this study. To detect efficiently the metal ion in solution, a desolvation unit was combined with the MPT ion source and the LTQ mass spectrometer. The experimental schematic was shown in Fig. 1a).

The desolvation unit Water samples, without any pretreatments, were pneumatically nebulized and generated the aerosols. The aerosols flow by carrying gas through a desolvation system to reduce microwave energy absorption by water as far as possible before the samples were introduced into the MPT central tube. The desolvation system comprised a heated tube and a dessication chamber. The heated tube is $25 \mathrm{~cm}$ long and is wrapped with heating tape monitored by a thermocouple and a heater controller (XMT61X, Beijing Huibang Science Technology Co. Ltd., China). The heater controller was set at $140^{\circ} \mathrm{C} \pm 5^{\circ} \mathrm{C}$. A 500-mL flask was filled with concentrated sulfuric acid (98\%) to further remove the $\mathrm{H}_{2} \mathrm{O}$ molecules from the aerosol. Finally, the dry aerosols were introduced into the plasma through the central tube of the MPT.

The MPT ion source The MPT was described previously as shown in Fig.1b) [23, 26], in brief, a central tube and the intermediate tube are concentric, with the central tube inside the intermediate tube. The supporting gas flow in the intermediate tube and the working gas flows in the central tube. This dual-flow structure is proved to be beneficial for the optimization of jet shape and plasma stabilization [27]. The central tube is made of copper with an outer diameter of $3 \mathrm{~mm}$ and inner diameter of $2 \mathrm{~mm}$. The outer tube $(26 \mathrm{~mm}$ o.d and 
$22 \mathrm{~mm}$ i.d) and the intermediate tube (5.5 $\mathrm{mm}$ o.d and $4.5 \mathrm{~mm}$ i.d.) are made of brass. The argon gas flowing from the argon cylinder is separate into two routes. One is directly introduced into the intermediate tube at a flow rate of about $500 \mathrm{~mL} / \mathrm{min}$, and another one is introduced into the pneumatic nebulizer with $800 \mathrm{~mL} / \mathrm{min}$ flow rate. The argon in the nebulizer creates the aerosols of the sample solution and carries the dried aerosol into the central tube. Two adjustable rotameters $(100-1000 \mathrm{ml} / \mathrm{min})$ are used to control the two argon flow rates. A $2450-\mathrm{MHz}$ voltage with a maximum power of $50 \mathrm{~W}$ is applied to the intermediate tube by the center conductor of a coaxial cable. The shielding ground of the coaxial cable is connected to the outer tube. The microwave field propagates in the annulus between the intermediate tube and the outer tube. The plasma is started with a spark, which is created manually by a short circuit between the intermediate tube and the inner tube. By optimizing these parameters, a stable visible cone-shaped plasma jet is generated on the top opening of the MPT. During the experiments, the MPT was fixed on a translate-stage with a coaxial distance $d$ about $1 \mathrm{~cm}$ form the ion inlet of LTQ mass spectrometer to the tip of the plasma.

The mass spectrometer The LTQ mass spectrometer coupled with the MPT source is set for the analysis of zinc and cadmium both in positive mode and negative mode with mainly parameters including the capillary voltage of $\pm(0-24) \mathrm{V}$ and the tube lens voltage of $\pm 52 \mathrm{~V}$. The temperature of the heated capillary was $150^{\circ} \mathrm{C}$. The mass spectra were collected with an average time of $0.5 \mathrm{~min}$. Ions of interest were isolated with a mass-to-charge window width of 0.6 units for collision-induced dissociation (CID) experiments by applying a collision energy (CE) of about 35\% (arbitrary unit defined by the MS manufacturer). The commercial software Xcalibur is inherent used for LTQ control and data processing.

\section{RESULTS AND DISCUSIONS}


Previous studies had shown that the excitation temperature of the MPT plasma is relatively high, about $800-2000 \mathrm{~K}[28,29]$, but the ionization degree is low, only $0.01 \%$, far less than that of ICP, $0.2 \%$ [30]. Moreover, the MPT plasma expose to the ambient surrounding, hence there are some characteristic groups, for instance, $\mathrm{NO}_{3}{ }^{-}, \mathrm{NH}_{2}{ }^{-}, \mathrm{H}_{2} \mathrm{O}$ and $\mathrm{OH}$ etc., which can be used as reagent ions to make the MPT mass spectra of metal elements easy assignment [20]. In general, the metal ions come into being a regular forms of $\mathrm{M}\left(\mathrm{NO}_{3}\right)_{\mathrm{n}}$ pulsing several $\mathrm{H}_{2} \mathrm{O}$ molecules or $\mathrm{OH}$ groups in MPT plasma, here $\mathrm{M}$ represents a metal element, since the $\mathrm{NO}_{3}{ }^{-}$is electrophilic while metal ions are general electron donor. Usually, the nitrate radical comes from the air surroundings, but not the sample solutions $[25,31]$. Moreover, depending on the number $\mathrm{n}$, the result group $\mathrm{M}\left(\mathrm{NO}_{3}\right)_{\mathrm{n}}$ can be a cation or anion, which provides an opportunity for the detection of metal elements in both positive mode and negative mode.

\section{The MPT Mass Spectra of Zinc and Cadmium in Positive Mode}

Zinc Zinc has five main isotopes, ${ }^{64} \mathrm{Zn}$ with a natural abundance $48.6 \%,{ }^{66} \mathrm{Zn}$ with a natural abundance $27.9 \%,{ }^{67} \mathrm{Zn}$ with a natural abundance $4.1 \%,{ }^{68} \mathrm{Zn}$ with a natural abundance 18.8 $\%$, and ${ }^{70} \mathrm{Zn}$ with a natural abundance $0.6 \%$. Fig. 2 showed the MPT mass spectra of zinc in positive mode collected in the range of 50-250Th with a 500 $\mu \mathrm{g} / \mathrm{L}$ zinc standard solution.

Obviously, there are three similar mass spectral bands, with main peaks at $m / z, 146,162$ and 180, respectively. Each spectral band comprises more than five peaks, which seems to conflict with the natural isotopic distribution of zinc. However, thinking about that there are abundant $\mathrm{OH}$ group in the plasma and the generation of zinc nitrate $\mathrm{OH}$ group is as easy as that of zinc nitrate $\mathrm{H}_{2} \mathrm{O}$ group, these spectral bands in Fig. 2 can be unambiguously assigned. For instance, the band of $m / z, 162$ is hybrid $\mathrm{Zn}\left(\mathrm{NO}_{3}\right) \cdot 2 \mathrm{OH}, \mathrm{Zn}\left(\mathrm{NO}_{3}\right) \cdot \mathrm{OH} \cdot \mathrm{H}_{2} \mathrm{O}$ and $\mathrm{Zn}\left(\mathrm{NO}_{3}\right) \cdot 2 \mathrm{H}_{2} \mathrm{O}$, as well as the band of $m / z .146$ is analogous to that of $m / z 162$ merely with $\mathrm{NO}_{2}$ replacing $\mathrm{NO}_{3}$. The band of $m / z 180$ seems that the band of $m / z, 162$ attach a $\mathrm{H}_{2} \mathrm{O}$ 
molecule. The detail assignment of these bands was summarized in Table 1. It is interesting to determine the mixing ratio, here then a simple algorithm is need. For the band of $m / z, 162$, without loss of generality, supposing the yielding of $\mathrm{Zn}\left(\mathrm{NO}_{3}\right) \cdot 2 \mathrm{OH}, \mathrm{Zn}\left(\mathrm{NO}_{3}\right) \cdot \mathrm{OH} \cdot \mathrm{H}_{2} \mathrm{O}$ and $\mathrm{Zn}\left(\mathrm{NO}_{3}\right) \cdot 2 \mathrm{H}_{2} \mathrm{O}$ in the MPT plasma are constant, and adopting the theoretical isotopic distribution values of zinc, then a linear equation set can be derived. By regression testing this algebraic system, the mixing ration of $\mathrm{Zn}\left(\mathrm{NO}_{3}\right) \cdot 2 \mathrm{OH}, \mathrm{Zn}\left(\mathrm{NO}_{3}\right) \cdot \mathrm{OH} \cdot \mathrm{H}_{2} \mathrm{O}$ and $\mathrm{Zn}\left(\mathrm{NO}_{3}\right) \cdot 2 \mathrm{H}_{2} \mathrm{O}$ can be determined as 1: 3.401: 3.239, as shown in Fig. 3a), b) and c). Then simulating results, i.e. the summation of that in Fig. 3a), b) and c), was shown in Fig. 3d) and was compared with the experimental data. As shown, at low mass side, the simulating results match well with the experimental data, but there is a certain deviation in high mass side, maybe due to the relatively low intensities. For the band of $m / z 146$ and 180, same algorithm was employed and the simulating results were also summarized in Table 1. It was worth noting that the group containing triple $\mathrm{OH}$ was excluded in the assignment of the spectral band of $m / z 180$, because $m / z 177$, should be assigned to ${ }^{64} \mathrm{Zn}\left(\mathrm{NO}_{3}\right) \cdot 3 \mathrm{OH}$, disappear in this spectrum. Presumably triple-OH group is difficult to produce in the MPT plasma.

Furthermore, the above qualitative analysis can be supported by the tandem mass spectrometry procedure. As a representative, Fig. 4 showed the $\mathrm{MS}^{\mathrm{n}}$ mass spectra of the ions of $m / z, 145$ and 146. Fig.4a) is the $\mathrm{MS}^{2}$ mass spectrum, the precursor ions of $m / z 145$ produce fragments at $m / z, 127,128,117$ and 82 by the lost of $\mathrm{H}_{2} \mathrm{O}, \mathrm{OH}$, a 28-Da group and a 63-Da group, respectively. The 28-Da group had been found frequently in the collision induced dissociation processes of nitrate complexes of many transition metal elements in positive mode $[25,31]$. The 63-Da group may be $\mathrm{NO}_{2} \bullet \mathrm{OH}$. The fragments of $m / z 127$ and 128 can be further dissociated both to generate mainly the sub-fragment at $m / z$ 110, as shown in Fig. 4b) and c). Finally, ${ }^{64} \mathrm{Zn}^{+}$is yielded from the sub-precursor ion of $m / z, 110$ in $\mathrm{MS}^{4}$ mass spectrum by throwing out the $\mathrm{NO}_{2}$ group (Fig. 4d). This dissociation series show that the ions of $\mathrm{m} / \mathrm{z}$ 
145 is $\left[{ }^{64} \mathrm{Zn}\left(\mathrm{NO}_{2}\right) \cdot \mathrm{OH} \cdot \mathrm{H}_{2} \mathrm{O}\right]^{+}$. The precursor ions of $\mathrm{m} / \mathrm{z}, 146$ have the same fragment pattern, as shown in Fig. 4e), and the main fragment ions of $\mathrm{m} / \mathrm{z}, 128$ dissociated along the route as shown in Fig. 4c) and d). The minor fragment of $\mathrm{m} / \mathrm{z} 129$ dissociated further along the similar way to yield the ultimate ions ${ }^{66} \mathrm{Zn}$ by losing consecutively the second $\mathrm{OH}$ group and $\mathrm{NO}_{2}$ group (Fig. $4 \mathrm{f}$ and g). Consequently, these experimental data approve that the ions of $\mathrm{m} / \mathrm{z} .146$ is the hybrid of $\left[{ }^{64} \mathrm{Zn}\left(\mathrm{NO}_{2}\right) \cdot 2 \mathrm{H}_{2} \mathrm{O}\right]^{+}$and $\left[{ }^{66} \mathrm{Zn}\left(\mathrm{NO}_{2}\right) \cdot 2 \mathrm{OH}\right]^{+}$.

Cadmium Analogously, the cadmium nitrate cation exhibits similar pattern. Fig. 5 showed the MPT mass spectrum of cadmium collected in the interval of m/z 100-240 Th. Three clear spectral bands, located at $\mathrm{m} / \mathrm{z} 195,211$ and 230 were also assigned to the hybrid of $\mathrm{Cd}\left(\mathrm{NO}_{3}\right) \cdot \mathrm{nOH} \cdot \mathrm{mH}_{2} \mathrm{O}, \mathrm{m}=0,1$ and $\mathrm{n}=0,1,2$. A direct identification by using the tandem mass spectrometry is necessary. For simple, only the MPT MS ${ }^{2}$ mass spectrum of $m / z 212$ and 211 were exhibited. Fig. 6 a) is that of the precursor ion of $m / z 212$, which mainly lost a $\mathrm{H}_{2} \mathrm{O}$ to produce the peak at $m / z$ 194. In the $\mathrm{MS}^{3}$ mass spectrum (Fig. 6 b), the sub-precursor ion of $m / z 194$ was isolated and then lost a second $\mathrm{H}_{2} \mathrm{O}$ molecule to produce the primary ions of $\mathrm{m} / \mathrm{z}$ 176 and a 28-Da group to obtain the signal at $m / z$ 166. The ions of $m / z 176$ can be further dissociated in $\mathrm{MS}^{4}$ experiments to generate the ultimate ions at $m / z$ 114, i.e. ${ }^{114} \mathrm{Cd}$, with the lost of $\mathrm{NO}_{3}$ group, as shown in Fig. 6 c). In Fig. 6 d), e) and f), the parallel fragmentation patterns with the corresponding fragment peaks shifting right 1-Th comparing to that of $m / z$ 211 were watched, which give obvious isotopic characteristics. Therefore, these CID processes verify that the signal in Fig.5 belong to the ions cadmium contained.

\section{The MPT Mass Spectra of Zinc and Cadmium in Negative Mode}

For zinc and cadmium elements, the positive MPT spectra are extremely complex since a lot of spectral lines of the metallic $\mathrm{H}_{2} \mathrm{O}$ groups and the metallic $\mathrm{OH}$ groups as well as their isotopes overlap, which prevents the exactly quantitative analysis using the positive mass 
spectrometry signal. However, relative to the complexity in positive mode, the negative MPT mass spectra show more concise.

Fig. 7 showed the MPT spectra of zinc and cadmium in negative mode. As shown in Fig.7 a), the spectral band at $m / z 250$ comprises five peaks, according with the five natural isotopes of zinc. Moreover, the intensity ratio of peaks at $\mathrm{m} / \mathrm{z}, 250,252,253,254,256$ is 1:0.563: $0.0975: 0.367: 0.017$, which is quite close to the theoretical value $1: 0.574: 0.084$ : 0.387: 0.012 . The spectral band can be assigned to $\mathrm{Zn}\left(\mathrm{NO}_{3}\right)_{3}{ }^{-}$, according with the rule aftermentioned. Similarly, the spectral band at $\mathrm{m} / \mathrm{z} 300$ in Fig. 7 b) can be also assigned to $\mathrm{Cd}\left(\mathrm{NO}_{3}\right)_{3}{ }^{-}$, where the experimental intensity ratio of peaks at $\mathrm{m} / \mathrm{z}, 292,294,296,298,299$, 300, 302 is 0.026: 0.023: 0.446: 0.455: 0.839: 0.411:1:0.245, almost according with the natural isotopic distribution of cadmium: $:{ }^{106} \mathrm{Cd}$ with a abundance $1.22 \%,{ }^{108} \mathrm{Cd}$ with a abundance $0.88 \%,{ }^{110} \mathrm{Cd}$ with a abundance $12.39 \%,{ }^{111} \mathrm{Cd}$ with a abundance $12.75 \%,{ }^{112} \mathrm{Cd}$ with a abundance $24 \%,{ }^{113} \mathrm{Cd}$ with a abundance $12.2 \%,{ }^{114} \mathrm{Cd}$ with a abundance $28.86 \%$, ${ }^{116} \mathrm{Cd}$ with a abundance $7.56 \%$,. More important, the signal-noise ratio is high enough so that the minimum distribution of natural isotopes, for instance, ${ }^{70} \mathrm{Zn},{ }^{106} \mathrm{Cd}$ and ${ }^{108} \mathrm{Cd}$, were all determined clearly in such negative MPT mass spectra. In addition, the negative MPT tandem mass spectra of zinc and cadmium are also regular, i.e. the zinc or cadmium nitrate anion will cast gradually away $\mathrm{NO}_{2}$ and $\mathrm{NO}_{3}$ group in $\mathrm{CID}$ processes, similar to other common transition metal elements. Fig. 8 showed the representative $\mathrm{MS}^{\mathrm{n}}$ mass spectra of $\left[{ }^{64} \mathrm{Zn}\left(\mathrm{NO}_{3}\right)_{3}\right]^{-}$. In the first dissociated step, the main product is the ions of $\mathrm{m} / \mathrm{z} 204$ by losing a $\mathrm{NO}_{2}$ group (Fig. 8a), and the fragment ions of $\mathrm{m} / \mathrm{z} 204$ will further generate the ions of $\mathrm{m} / \mathrm{z}$ 172 and $m / z, 142$ with the lost of $\mathrm{O}_{2}$ and $\mathrm{NO}_{3}$, respectively (in Fig. 8 b). For cadmium, parallel fragment pattern can also be obtained (not shown). These characteristic fragments in $\mathrm{MS}^{\mathrm{n}}$ mass spectra are used to monitor quantitatively the concentrations of zinc and cadmium elements in water. 


\section{Semi-quantitative analysis of zinc and cadmium in negative mode}

Nonambiguous mass spectral structure and low background noise make us adopt the negative mode to test the analysis capacity for zinc and cadmium. We measured the limit of detection (LOD) values for zinc and cadmium by using $\mathrm{m} / z, 250$ and 300 in the negative MPT mass spectra of zinc and cadmium as monitoring signal and reducing the concentrations down until the signal decayed to 3 times of noise level. The results were $15 \mu \mathrm{g} / \mathrm{L}$ for zinc and $5 \mu \mathrm{g} / \mathrm{L}$ for cadmium, respectively. Although these values are much larger than those got in ICP-MS (Table 2), they are almost close to the results obtained in ICP-AES and can meet the real requirement in detection of metal elements in water [32]. In addition, the analysis of a single water sample can be finished in 5 6 minutes. Thus this novel MPT mass spectrometry method provides an alternative approach for field analysis of water inspection.

\section{CONCLUSIONS}

Over all, we developed a MPT-MS method for the analysis of zinc and cadmium metal elements in water. We studied the MPT mass spectra of zinc and cadmium in both positive and negative modes, and found that the positive MPT mass spectra are complicated owing to the hybrid of metal nitrate $\mathrm{OH}$ group and metal nitrate $\mathrm{H}_{2} \mathrm{O}$ group, thus the positive mode is not suitable for the analysis of zinc and cadmium. However, the negative mode is regular and the sensitivity can achieve at about the levels of $10 \mu \mathrm{g} / \mathrm{L}$. Therefore, this method will have highly potential applications in quality monitoring of zinc and cadmium ions in water. More promisingly, MPT-MS can be used as the supplement of ICP-MS for the detection of trace metal elements in water.

\section{AUTHOR INFORMATION}




\section{Notes}

The authors declare no competing financial interest and no conflicts of interest.

\section{Acknowledgements}

This work was supported by the National Ministry of Science and Technology of China, the National Science and Technology Support Program of China (2011YQ14015009) and Chinese National Science Foundation (No.21565003). The authors are also grateful for the supporting of 2011 collaborative innovation center in mass spectrometry science and instrumentation, East China University of Technology. 


\section{REFERENCE}

[1] M. Brys, A.D.Nawrocka, E. Miekos, C. Zydek, M. Foksinski, A. Barecki, W. M. Krajewska, Zinc and cadmium analysis in human prostate neoplasms. Biol. Trace Elem. Res. 59(1997) 145-152.

[2] C. L. Keen, M. E. Gershwin, Zinc deficiency and immune function. Annu Rev Nutr, 10(1990) 415-431.

[3] K. M. Hambidge, N. F. Krebs, Zinc deficiency: a special challenge. J. Nutr. 137(2007) 1101-1105.

[4] A. Sigel, H. Sigel, R. K. Sigel, Cadmium: From Toxicity to Essentiality, Metal Ions in Life Sciences, Vol.11, Springer, 2013.

[5] K. Nogawa, E. Kobayashi, Y. Okubo, Y. Suwazono, Environmental cadmium exposure, adverse effects and preventive measures in Japan. Biometals, 17(2004) 581-587.

[6] C. C. Bridges, R. K. Zalups, Molecular and ionic mimicry and the transport of toxic metals. Toxicol. Appl. Pharmacol., 204(2005) 274-308.

[7] B. J. Julin, A. Wolk, L. Bergkvist, M. Bottai, A. Akesson, Dietary cadmium exposure and risk of postmenopausal breast cancer: a population-based prospective cohort study. Cancer Res., 72(2012) 1459-1466.

[8] Z. R. Nan, J. J. Li, J. M. Zhang, G. D. Cheng, Cadmium and zinc interactions and their transfer in soil-crop system under actual field conditions. Sci. Total Environ., 285(2002) 187-195.

[9] M. Piotrowska, S. Dudka, A. Chlopecka, Effect of elevated concentrations of Cd and Zn in soil on spring wheat yield and the metal contents of the plants. Water air and soil pollution, 76(1994) 333-341.

[10] H. Pleijel, Effects of ozone on zinc and cadmium accumulation in wheat- dose-response functions and relationship with protein, grain yield, and harvest index. Ecol Evol. 2(2012) 3186-3194.

[11] M. Mench, E. Martin, Mobilization of cadmium and other metals from two soils by root exudates of Zea mays L., Nicotiana tabacum L. and Nicotiana rustica L. Plant \& Soil, 132(1991) 187-196

[12] J. Ogunlewe, D. N. Osegbe, Zinc and cadmium concentrations in indigenous blacks with normal, hypertrophic, and malignant prostate. Cancer, 63(1989) 1388-1392.

[13] Q. L. Liu, L. X. Feng, C. X. Yuan, L. Zhang, S. M. Shuang, C. Dong, Q. Hu and M. M. F. Choi, A highly selective fluorescent probe for cadmium ions in aqueous solution and living cells. Chem. Commun. 50(2014) 2498-2501.

[14] H. Kipphardt, M. Czerwensky and R. Matschat, ICP-MS analysis of high purity molybdenum used as SI-traceable standard of high metrological quality. J. Anal. At. Spectrom. 20(2005) 28-34.

[15] W. R. Keyes and J. R. Turnlund, Determination of molybdenum and enriched Mo stable isotope concentrations in human blood plasma by isotope dilution ICP-MS. J. Anal. At. Spectrom. 17(2002) 1153-1156.

[16] A. T. Townsend, K. A. Miller, S. McLean and S. Aldous, The determination of copper, zinc, cadmium and lead in urine by high resolution ICP-MS. J. Anal. At. Spectrom. 13(1998) 1213-1219.

[17] GB 5750.6-2006. Standard examination methods for drinking water-metal Parameters. National Standards of the People's Republic of China.

[18] T. Q. Zhang, W. Zhou, W. Jin, J. G. Zhou, E. Handberg, Z. Q. Zhu, H. W. Chen, Q. H. Jin, Direct desorptionionization of analytes by microwave plasma torch for ambient mass spectrometric analysis. J. Mass Spectrom. 48(2013) 669-676. 
[19] Q. H. Jin, F. Wang, C. Zhu, D. M. Chambers, G. M. Hieftje, Atomic emission detector for gas chromatography and supercritical fluid chromatography. J. Anal. At. Spectrom. $5(1990)$ 487-494.

[20] X. F. Zhan, Z. J. Zhao, X. Yuan, Q. H. Wang, D. D. Li, H. Xie, X. M. Li, M. G. Zhou, Y. X. Duan, Microwave-Induced Plasma Desorption/Ionization Source for Ambient Mass Spectrometry. Anal. Chem. 85(2013) 4512-4519.

[21] Y. X. Duan, Y. X. Su, Z. Jin, A new, simple, compact GD-MIP tandem ion source for elemental time-of-flight mass spectrometry. J. Anal. Atom. Spectrom. 15 (2000) 12891291.

[22] Y. X. Su, Y. X. Duan, Z. Jin, Development and evaluation of a glow discharge microwave-induced-plasma tandem source for time-of-flight mass spectrometry. Anal. Chem. 72(2000) 5600-5605.

[23] J. H. Barnes IV, O. A. Grøn, G. M. Hieftje, Characterization of an argon microwave plasma torch coupled to a Mattauch-Herzog geometry mass spectrometer. J. Anal. Atom. Spectrom. 17(2002) 1132-1136.

[24] G. Feng, Y. Huan, Y. Cao, S. Wang, X. Wang, J. Jiang, A. Yu, Q. Jin, H. Yu, Development of a miniature simultaneous MPT spectrometer. Microchem. j. 76(2004) 17-22.

[25] X. H. Xiong, T. Jiang, W. H. Qi, J. Zuo, M. L. Yang, Q. Fei, S. J. Xiao, A. M. Yu, Z. Q. Zhu, H. W. Chen. Some Rare Earth Elements Analysis by Microwave Plasma Torch Coupled with the Linear Ion Trap Mass Spectrometry. Int. J. Anal. Chem. 2015(2015) 156509.

[26] W. Yang, H. Zhang, A. M. Yu, Q. H. Jin, Microwave plasma torch analytical atomic spectrometry. Microchem. j. 66(2000) 147-170.

[27] T. Q. Wan, D. D.Yu, T. Q. Zhang, X. W. Zhang, J. G. Zhou, A rapid method for detection of gunshot residue using microwave plasma torch-mass spectrometry. Procedia Engineering 7(2010) 22-27.

[28] S. H. Wang, Dissertation: Studies on the diagnoses and application of oxygen- shielded argon microwave plasma torch(OS-ArMPT), University of Jilin, 2006.

[29] M. Huang, D. Hanselman, Q. Jin, G. M. Hieftje, Non-thermal features of atmosphericpressure argon and helium microwave-induced plasmas observed by laser-light Thomson scattering and Rayleigh scattering. Spectrochim. Acta Part B 45 (1990) 13391352.

[30] K. J. Jankowski, E. Reszke, Microwave induced plasma analytical spectrometry, Vol. 12, RSC, 2010.

[31] T. Jiang, Q. J. Liu, L.F. Yi, W. H. Qi, B. Ceng, Y. M. Zhou, Z. Q. Zhu, H. W. Chen. Direct Detection of Cadmium in Aqueous Solution Using Microwave Plasma Torch Coupled with Quadrupole Mass Spectrometry. J. Instrum. Anal. 35(2016) 79-84.

[32] GB 5749.6-2006. Standards for Drinking Water Quality. National Standards of the People's Republic of China. 
Table 1 The Assignment of MPT Mass Spectrum of Zinc in Positive Mode

\begin{tabular}{|c|c|c|c|c|}
\hline $\begin{array}{l}\text { Band } \\
(m / z)\end{array}$ & $\begin{array}{l}\text { Peak } \\
(\mathrm{m} / \mathrm{z})\end{array}$ & Assignment & $\begin{array}{c}\text { Relative } \\
\text { Intensity }(\%)\end{array}$ & $\begin{array}{l}\text { Simulating } \\
\text { Values }(\%)\end{array}$ \\
\hline \multirow{11}{*}{146} & 144 & ${ }^{64} \mathrm{Zn}\left(\mathrm{NO}_{2}\right) \cdot 2 \mathrm{OH}$ & 2.384 & 2.384 \\
\hline & 145 & ${ }^{64} \mathrm{Zn}\left(\mathrm{NO}_{2}\right) \cdot \mathrm{OH} \cdot \mathrm{H}_{2} \mathrm{O}$ & 11.080 & 11.080 \\
\hline & 146 & ${ }^{64} \mathrm{Zn}\left(\mathrm{NO}_{2}\right) \cdot 2 \mathrm{H}_{2} \mathrm{O},{ }^{66} \mathrm{Zn}\left(\mathrm{NO}_{2}\right) \cdot 2 \mathrm{OH}$ & 14.306 & 14.306 \\
\hline & 147 & ${ }^{66} \mathrm{Zn}\left(\mathrm{NO}_{2}\right) \cdot \mathrm{OH} \cdot \mathrm{H}_{2} \mathrm{O},{ }^{67} \mathrm{Zn}\left(\mathrm{NO}_{2}\right) \cdot 2 \mathrm{OH}$ & 8.766 & 6.562 \\
\hline & 148 & ${ }^{{ }^{6} \mathrm{Zn}\left(\mathrm{NO}_{2}\right) \cdot{ }^{68} \mathrm{H} \mathrm{Zn}\left(\mathrm{NO}_{2}\right) \cdot 2 \mathrm{OH}}$ & 8.766 & 9.283 \\
\hline & 149 & ${ }^{68} \mathrm{Zn}\left(\mathrm{NO}_{2}\right) \cdot \mathrm{OH} \cdot \mathrm{H}_{2} \mathrm{O},{ }^{67} \mathrm{Zn}\left(\mathrm{NO}_{2}\right) \cdot 2 \mathrm{H}_{2} \mathrm{O}$ & 4.418 & 5.377 \\
\hline & 150 & ${ }^{6} \mathrm{Zn}\left(\mathrm{NO}_{2}\right) \cdot 2 \mathrm{H}_{2} \mathrm{O},{ }^{70} \mathrm{Zn}\left(\mathrm{NO}_{2}\right) \cdot 2 \mathrm{OH}$ & 4.698 & 5.034 \\
\hline & 151 & ${ }^{70} \mathrm{Zn}\left(\mathrm{NO}_{2}\right) \cdot \mathrm{OH} \cdot \mathrm{H}_{2} \mathrm{O}$ & -- & 0.137 \\
\hline & 152 & ${ }^{70} \mathrm{Zn}\left(\mathrm{NO}_{2}\right) \cdot 2 \mathrm{H}_{2} \mathrm{O}$ & -- & 0.159 \\
\hline & 160 & ${ }^{64} \mathrm{Zn}\left(\mathrm{NO}_{3}\right) \cdot 2 \mathrm{OH}$ & 26.227 & 26.198 \\
\hline & 161 & ${ }^{64} \mathrm{Zn}\left(\mathrm{NO}_{3}\right) \cdot \mathrm{OH} \cdot \mathrm{H}_{2} \mathrm{O}$ & 89.201 & 89.189 \\
\hline \multirow{6}{*}{162} & 162 & ${ }^{64} \mathrm{Zn}\left(\mathrm{NO}_{3}\right) \cdot 2 \mathrm{H}_{2} \mathrm{O},{ }^{66} \mathrm{Zn}\left(\mathrm{NO}_{3}\right) \cdot 2 \mathrm{OH}$ & 100.000 & 100.000 \\
\hline & 163 & ${ }^{66} \mathrm{Zn}\left(\mathrm{NO}_{3}\right) \cdot \mathrm{OH} \cdot \mathrm{H}_{2} \mathrm{O},{ }^{67} \mathrm{Zn}\left(\mathrm{NO}_{3}\right) \cdot 2 \mathrm{OH}$ & 61.431 & 53.411 \\
\hline & 164 & $\begin{array}{c}{ }^{66} \mathrm{Zn}\left(\mathrm{NO}_{3}\right) \cdot{ }^{68} \mathrm{H} \mathrm{H}_{2} \mathrm{O},{ }^{67} \mathrm{Zn}\left(\mathrm{NO}_{3}\right) \cdot 2 \mathrm{OH} \\
\end{array}$ & 73.492 & 66.432 \\
\hline & 165 & ${ }^{68} \mathrm{Zn}\left(\mathrm{NO}_{3}\right) \cdot \mathrm{OH} \cdot \mathrm{H}_{2} \mathrm{O},{ }^{67} \mathrm{Zn}\left(\mathrm{NO}_{3}\right) \cdot 2 \mathrm{H}_{2} \mathrm{O}$ & 48.107 & 41.669 \\
\hline & 166 & ${ }^{68} \mathrm{Zn}\left(\mathrm{NO}_{3}\right) \cdot 2 \mathrm{H}_{2} \mathrm{O},{ }^{70} \mathrm{Zn}\left(\mathrm{NO}_{3}\right) \cdot 2 \mathrm{OH}$ & 38.780 & 33.189 \\
\hline & 167 & ${ }^{70} \mathrm{Zn}\left(\mathrm{NO}_{3}\right) \cdot \mathrm{OH} \cdot \mathrm{H}_{2} \mathrm{O}$ & 5.259 & 1.1011 \\
\hline & 168 & ${ }^{70} \mathrm{Zn}\left(\mathrm{NO}_{3}\right) \cdot 2 \mathrm{H}_{2} \mathrm{O}$ & 3.787 & 1.0489 \\
\hline \multirow{10}{*}{180} & 177 & ${ }^{64} \mathrm{Zn}\left(\mathrm{NO}_{3}\right) \cdot 3 \mathrm{OH}$ & -- & -- \\
\hline & 178 & ${ }^{64} \mathrm{Zn}\left(\mathrm{NO}_{3}\right) \cdot 2 \mathrm{OH} \cdot \mathrm{H}_{2} \mathrm{O}$ & 5.260 & 5.260 \\
\hline & 179 & ${ }^{64} \mathrm{Zn}\left(\mathrm{NO}_{3}\right) \cdot \mathrm{OH} \cdot 2 \mathrm{H}_{2} \mathrm{O}$ & 18.654 & 18.654 \\
\hline & 180 & ${ }^{64} \mathrm{Zn}\left(\mathrm{NO}_{3}\right) \cdot 3 \mathrm{H}_{2} \mathrm{O},{ }^{66} \mathrm{Zn}\left(\mathrm{NO}_{3}\right) \cdot 2 \mathrm{OH} \cdot \mathrm{H}_{2} \mathrm{O}$ & 51.332 & 51.332 \\
\hline & 181 & ${ }^{66} \mathrm{Zn}\left(\mathrm{NO}_{3}\right) \cdot \mathrm{OH} \cdot 2 \mathrm{H}_{2} \mathrm{O},{ }^{67} \mathrm{Zn}\left(\mathrm{NO}_{3}\right) \cdot 2 \mathrm{OH} \cdot \mathrm{H}_{2} \mathrm{O}$ & 16.339 & 11.153 \\
\hline & 182 & $\begin{array}{c}{ }^{66} \mathrm{Zn}\left(\mathrm{NO}_{3}\right) \cdot 3 \mathrm{H}_{2} \mathrm{O},{ }^{67} \mathrm{Zn}\left(\mathrm{NO}_{3}\right) \cdot \mathrm{OH} \cdot 2 \mathrm{H}_{2} \mathrm{O} \\
{ }^{68} \mathrm{Zn}\left(\mathrm{NO}_{3}\right) \cdot 2 \mathrm{OH} \cdot \mathrm{H}_{2} \mathrm{O}\end{array}$ & 34.712 & 31.343 \\
\hline & 183 & ${ }^{67} \mathrm{Zn}\left(\mathrm{NO}_{3}\right) \cdot 3 \mathrm{H}_{2} \mathrm{O},{ }^{68} \mathrm{Zn}\left(\mathrm{NO}_{3}\right) \cdot \mathrm{OH} \cdot 2 \mathrm{H}_{2} \mathrm{O}$ & 12.553 & 11.292 \\
\hline & 184 & ${ }^{68} \mathrm{Zn}\left(\mathrm{NO}_{3}\right) \cdot 3 \mathrm{H}_{2} \mathrm{O},{ }^{70} \mathrm{Zn}\left(\mathrm{NO}_{3}\right) \cdot 2 \mathrm{OH} \cdot \mathrm{H}_{2} \mathrm{O}$ & 23.352 & 18.754 \\
\hline & 185 & ${ }^{70} \mathrm{Zn}\left(\mathrm{NO}_{3}\right) \cdot \mathrm{OH} \cdot 2 \mathrm{H}_{2} \mathrm{O}$ & 3.787 & 0.230 \\
\hline & 186 & ${ }^{70} \mathrm{Zn}\left(\mathrm{NO}_{3}\right) \cdot 3 \mathrm{H}_{2} \mathrm{O}$ & 2.595 & 0.596 \\
\hline
\end{tabular}


Table 2 Comparing the LOD of MPT-MS with ICP-MS and ICP-AES for detection of zinc and cadmium in water $(\mu \mathrm{g} / \mathrm{L})$

\begin{tabular}{ccc}
\hline & $\mathrm{Zn}$ & $\mathrm{Cd}$ \\
\hline LOD in MPT-LTQ MS in negative & 15 & 5 \\
mode & 0.8 & 0.06 \\
LOD in ICP-MS[17] & 1 & 4 \\
LOD in ICP-AES[17] & 1000 & 5 \\
Ref.32 &
\end{tabular}



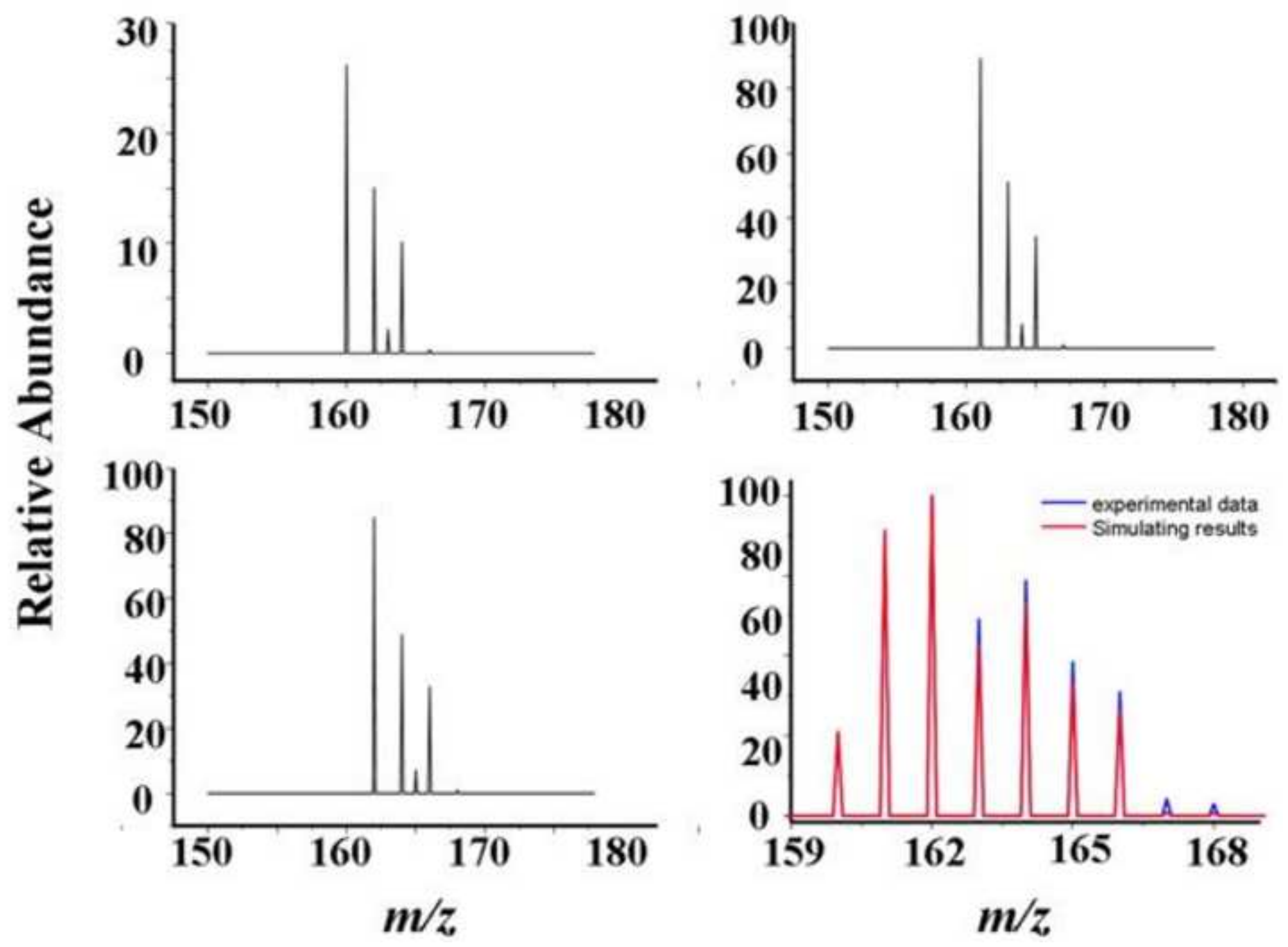

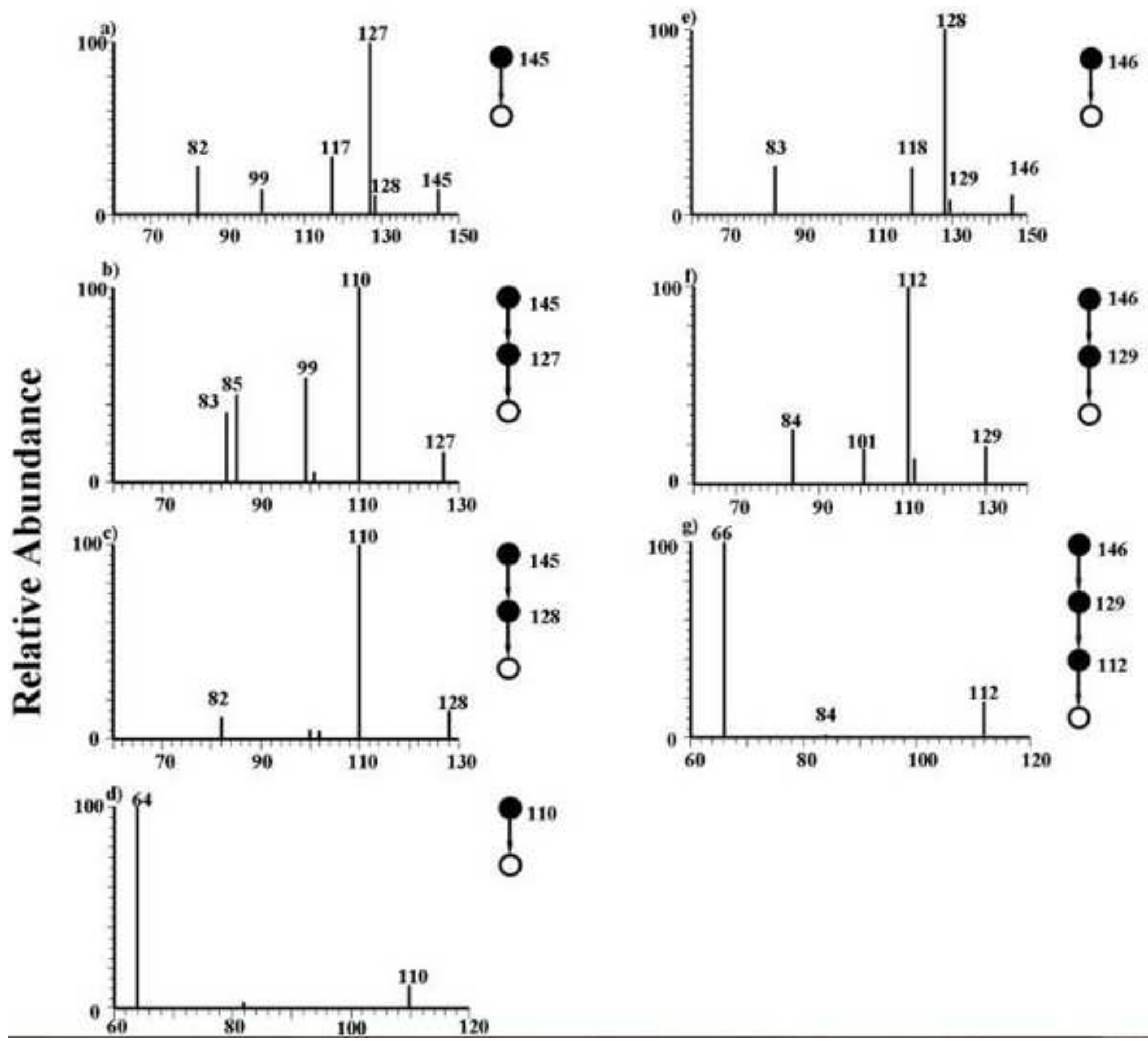


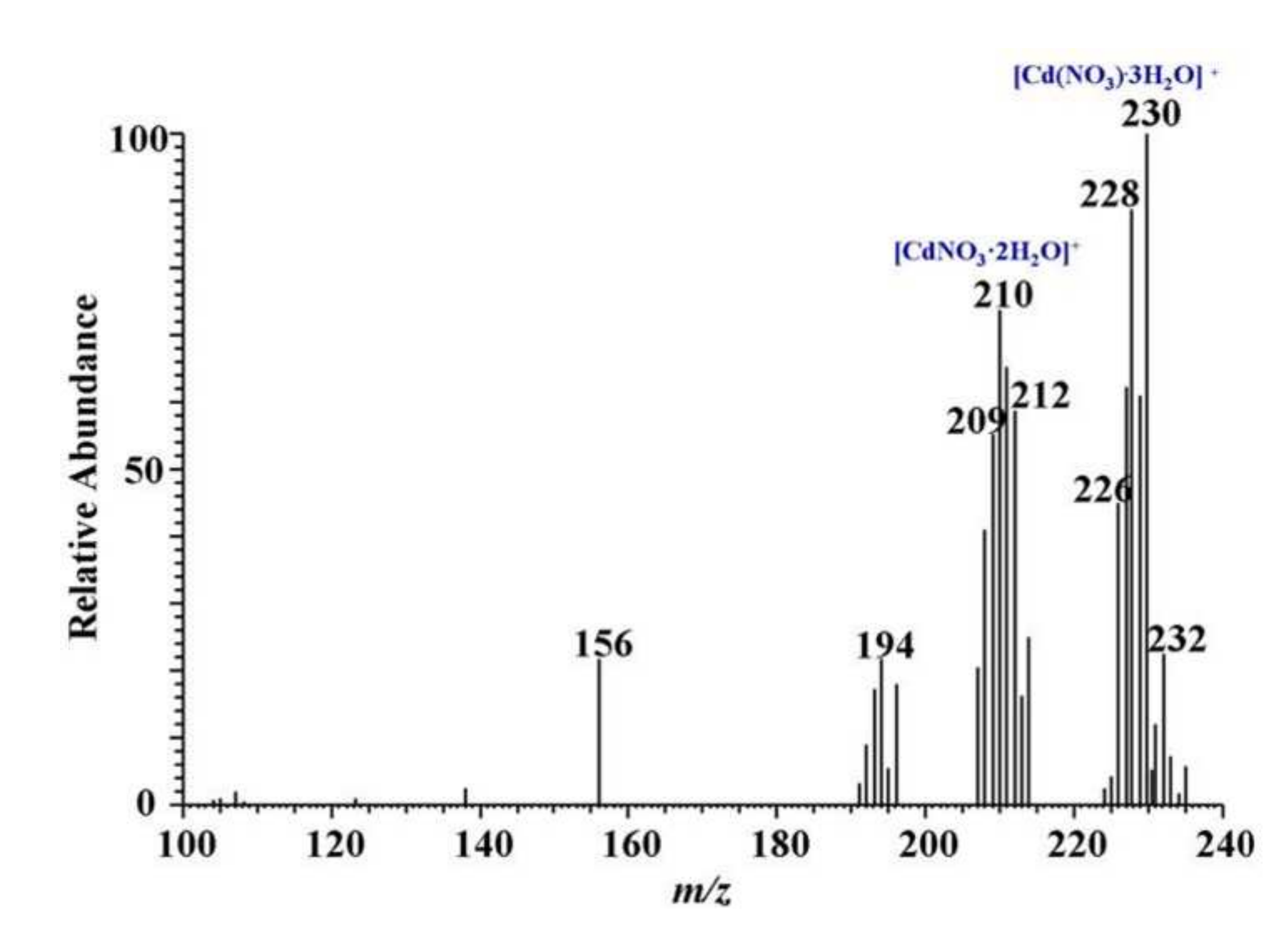

. 

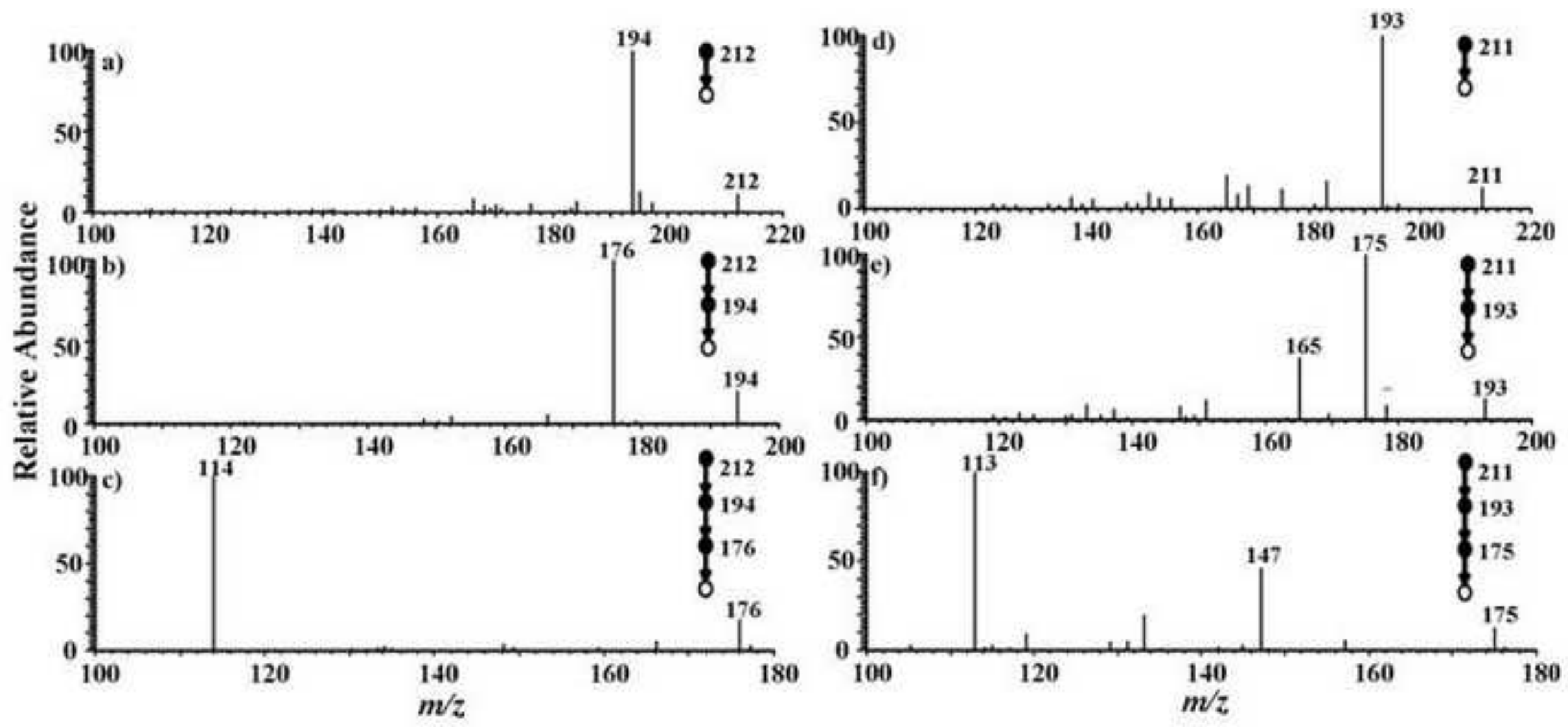


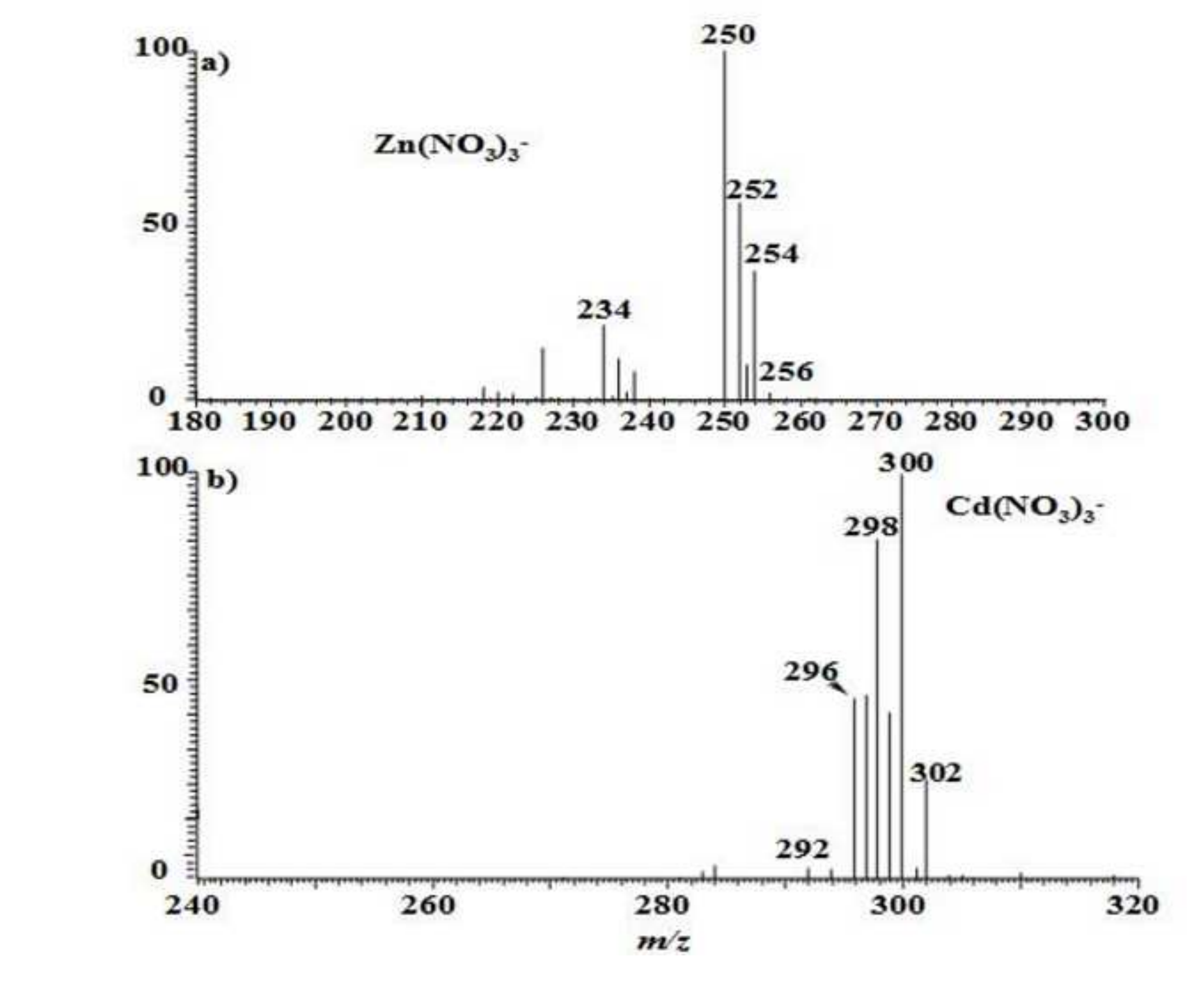

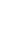

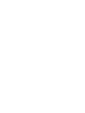

.

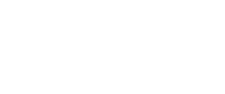

-
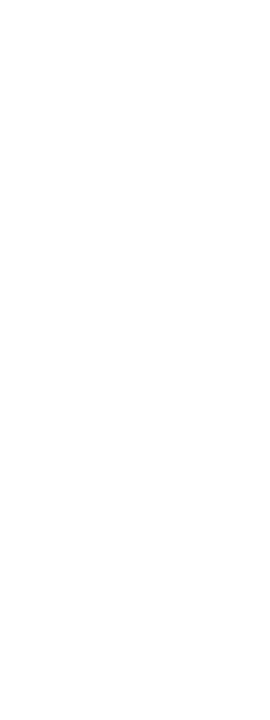

.
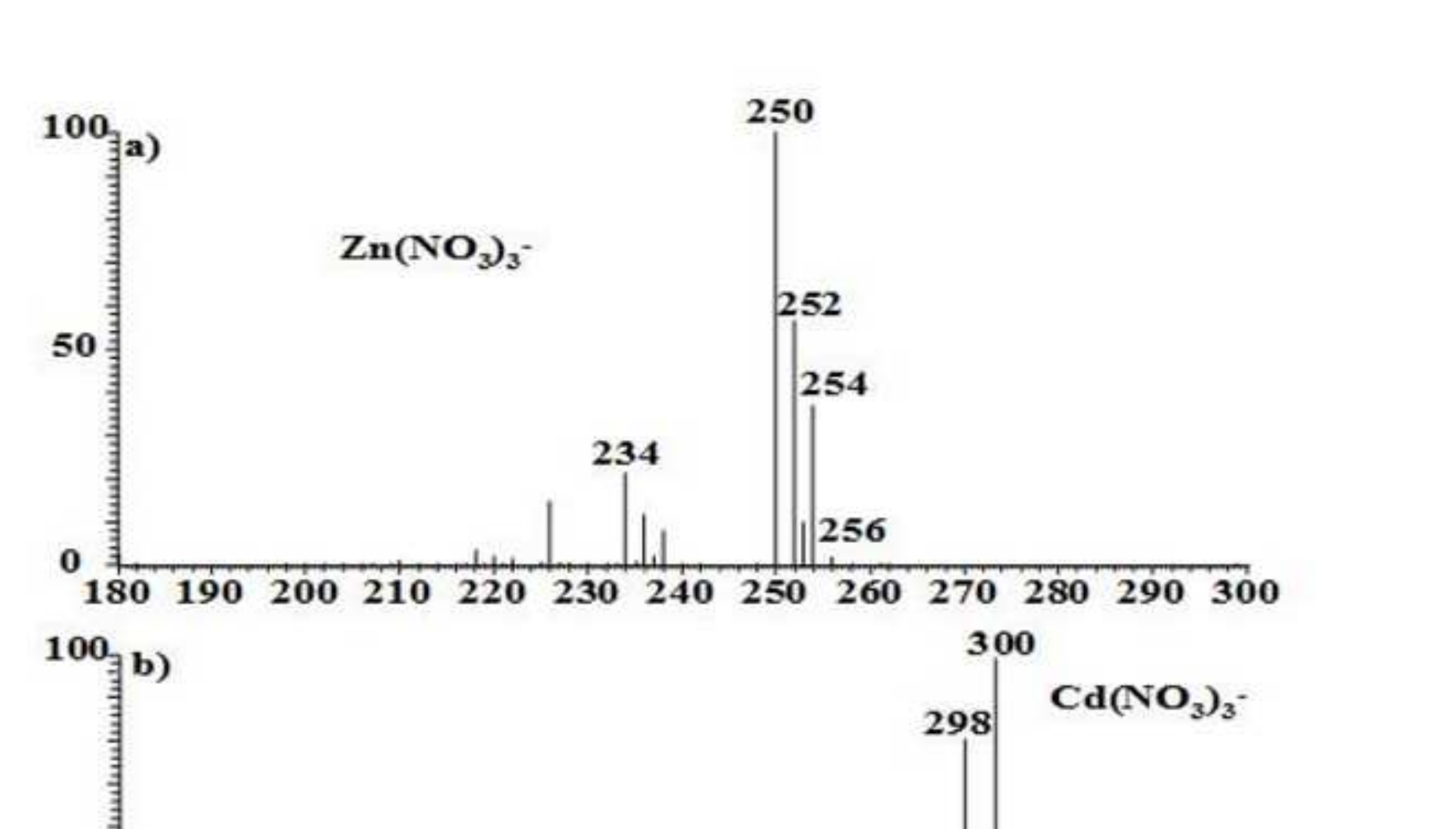


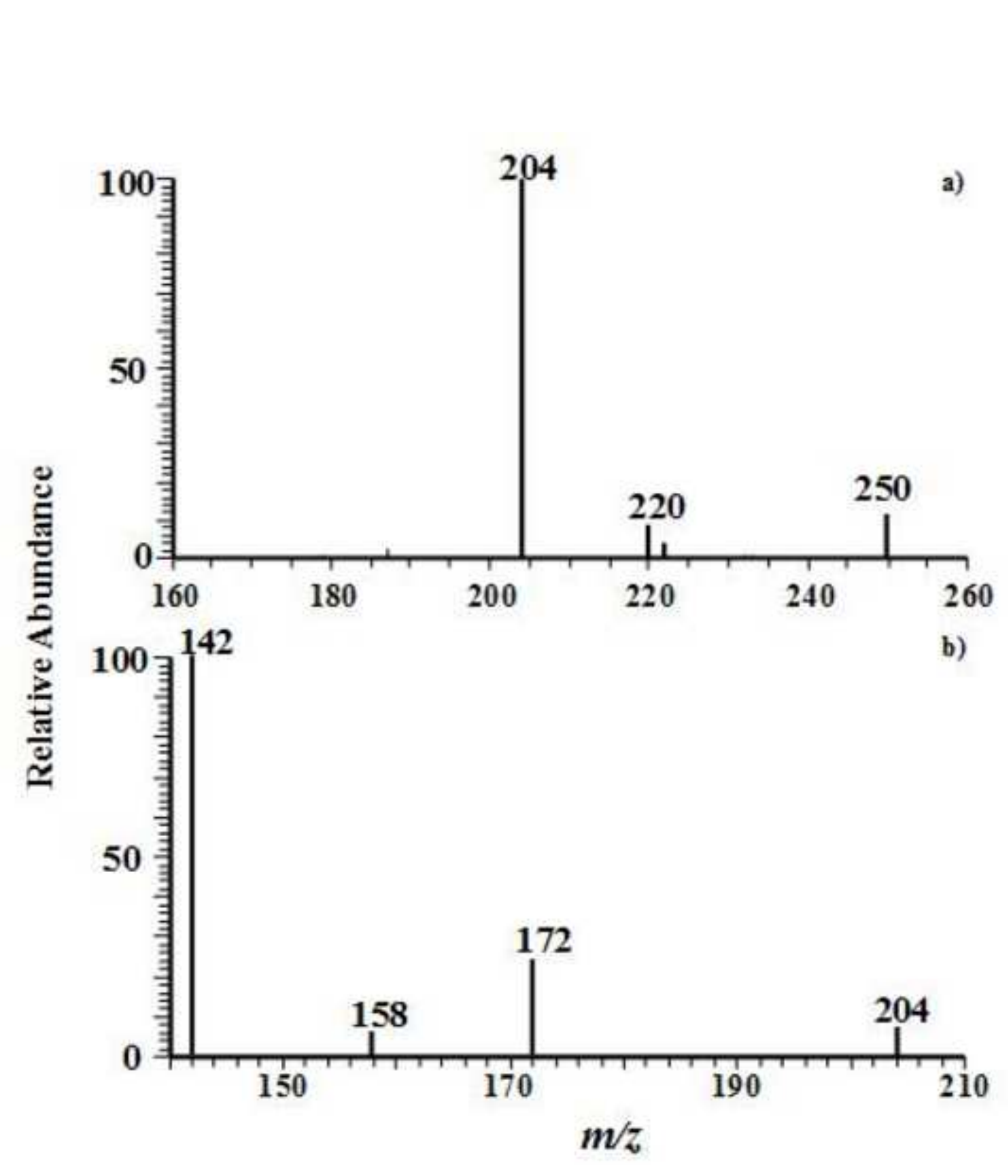

Figure



Fure

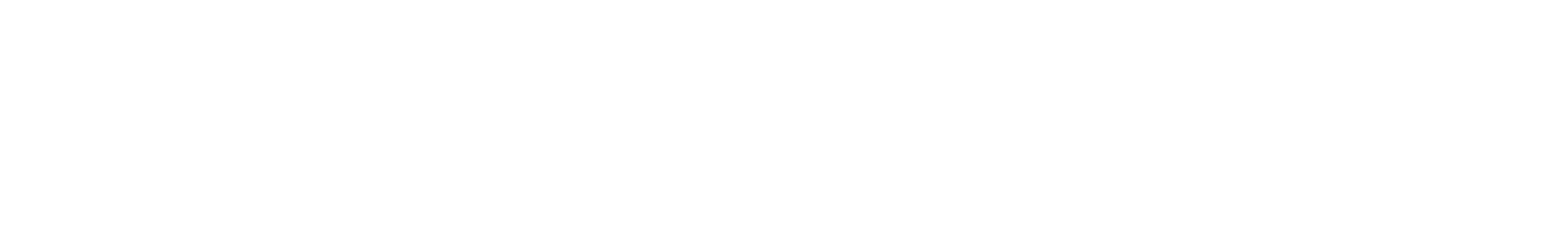

.

.

.

.

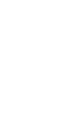
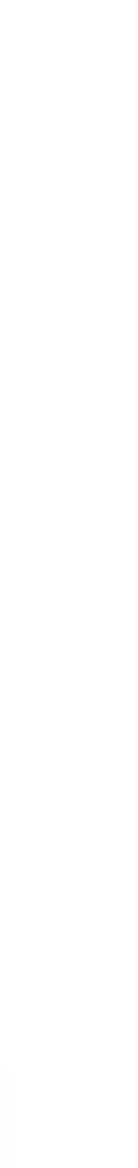


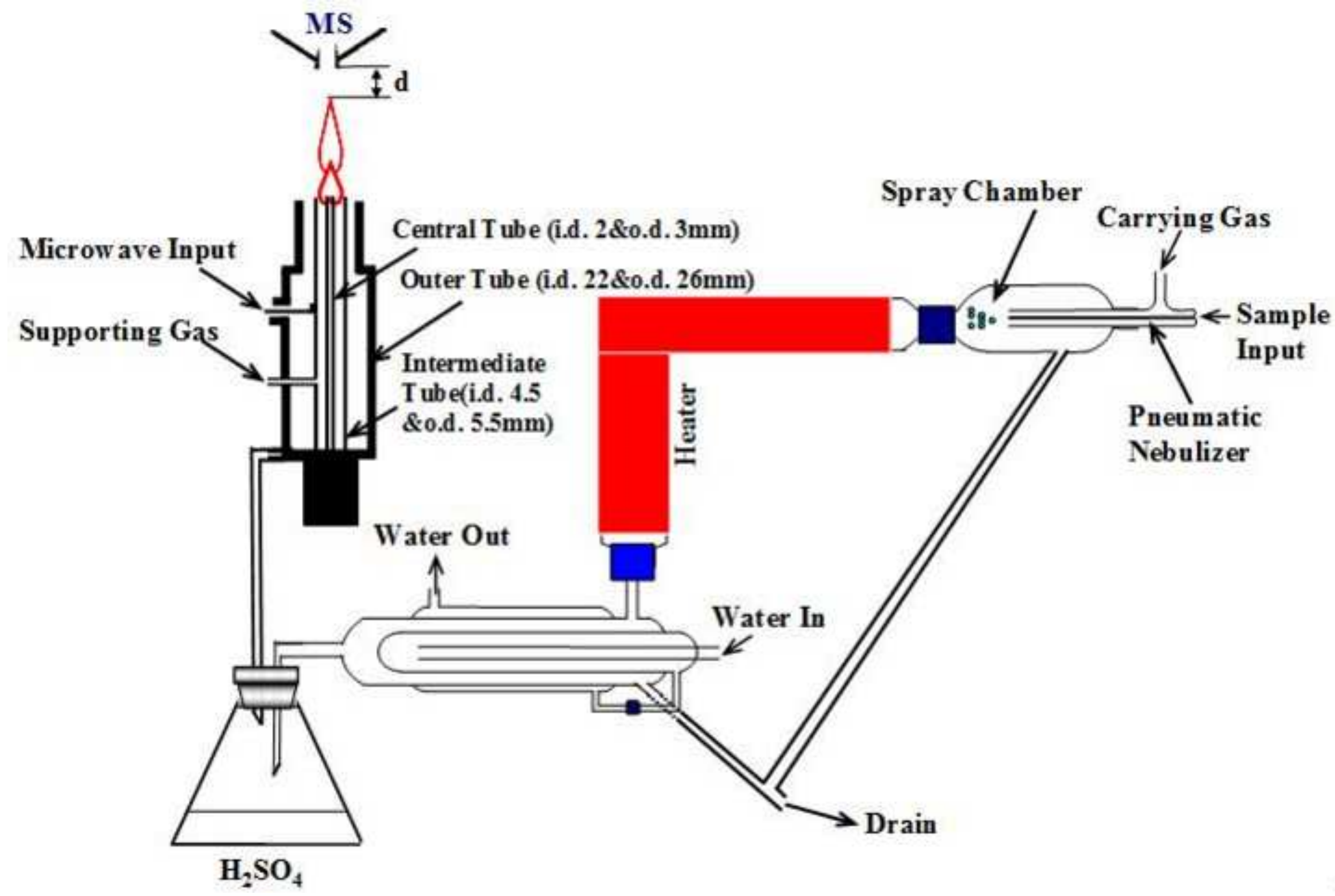




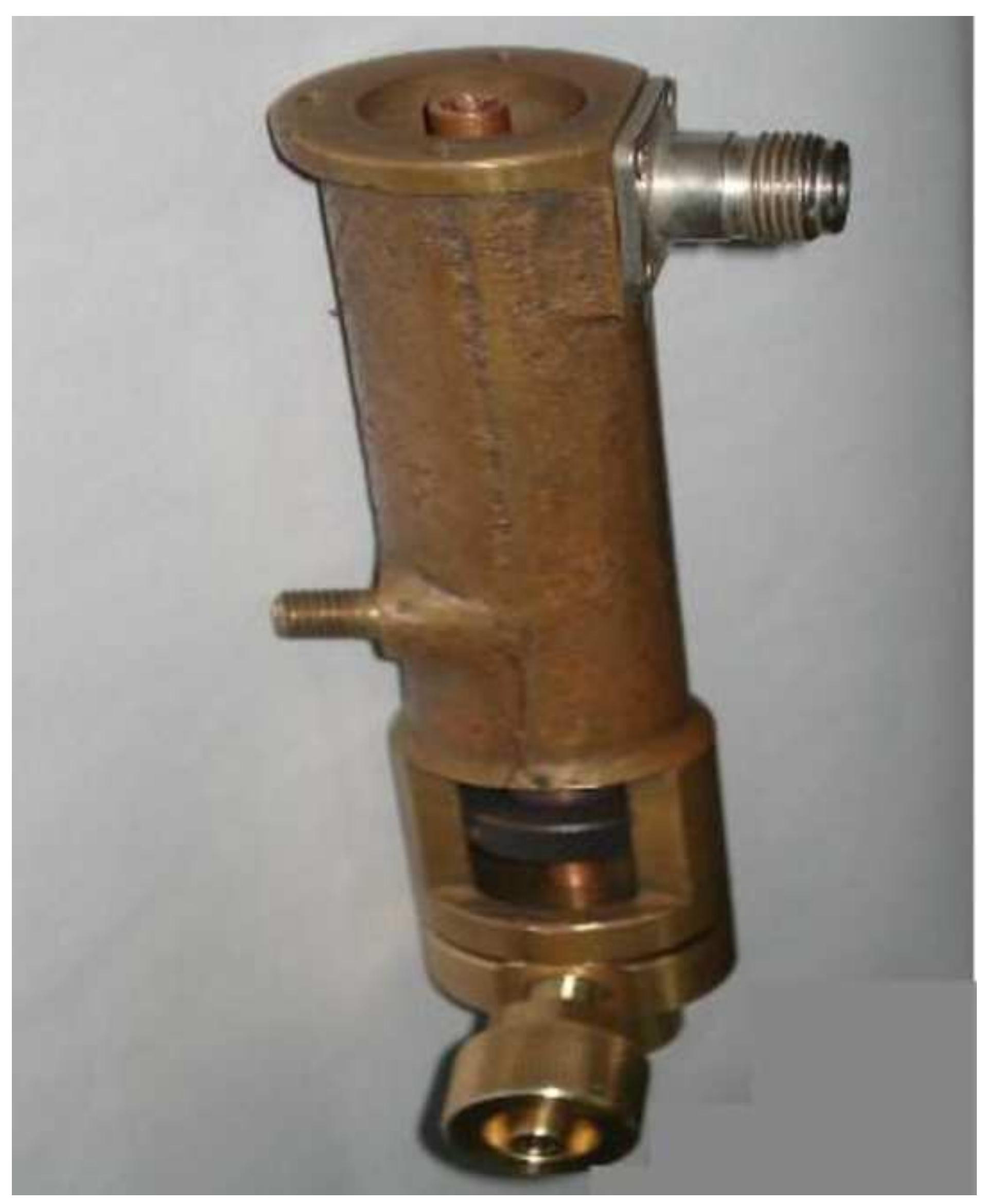

Figure

\section{Figure}

(

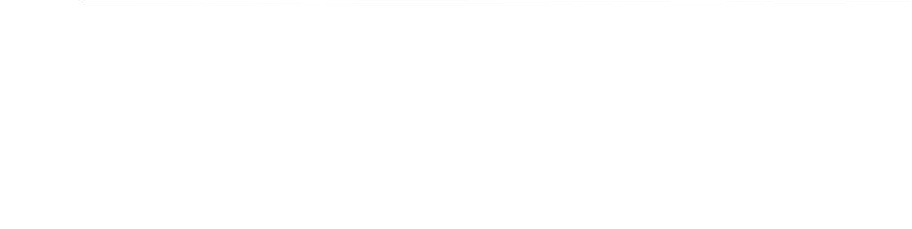


